\title{
Gustav Holst'un Gezegenler Süiti Adlı Yapıtının Sembolik İzdüşümü ve Analizi
}

\section{The Symbolical Projection and Analysis of Gustav Holst's the Planets}

\author{
Dilara Gözde ARAZ²
}

DOI: 10.26650/CONS2019-0005

'Istanbul Üniversitesi Devlet Konservatuvarı, İstanbul, Türkiye

\section{ORCID: D.G.A. 0000-0002-3206-8830}

Sorumlu yazar/Corresponding author: Dilara Gözde Araz,

İstanbul Üniversitesi Devlet Konservatuvarı, İstanbul, Türkiye

E-posta/E-mail: dgaraz@istanbul.edu.tr

Başvuru/Submitted: 13.03 .2019

Revizyon Talebi/Revision Requested: 06.06.2019

Son Revizyon/Last Revision Received:

14. 06.2019

Kabul/Accepted: 24.06 .2019

Online Yayın/Published Online: 28.06.2019

Atıf/Citation: Araz, D. G. (2019). Gustav Holst'un Gezegenler Süiti adlı yapııının sembolik izdüşümü ve analizi. Konservatoryum - Conservatorium, 6(1), 65-90.

https://doi.org/10.26650/CONS2019-0005

\section{Öz}

Gustav Holst (1874-1934) 20. yüzyılın ilk yarısında eserler vermiş ve yaşadığı dönemin müzikal yaklaşımlarının etkisinde kalmış İngiliz besteci ve müzik eğitimcisidir. Yaşadığı dönemin sosyokültürel şartlarından etkilenmiş, müziğinde geleneksel İngiliz halk müziği öğelerini, çeşitli inanışlara ve mitolojilere ait sembolleri kendine özgün bir üslup ile kaynaştırmıştır. Gerek yaşadığı dönemde ve gerekse kendinden sonra gelen bestecilere önemli ölçüde esin kaynağı olmuştur. Bu makale literatür taraması ve araştırma yöntemleri kullanılarak Gustav Holst'un, en önemli yapıtlarından olan Gezegenler Süiti adlı eserini yazarken esinlendiği sembolizmin araştırılmasını ve bu sembolizmi bestecinin eserine nasıl yansıttığının incelenmesini konu edinir. Makalede Gustav Holst'un yaşamı, müzikal anlayışı ve müzikal anlayışına etki eden unsurlar irdelendikten sonra bestecinin Gezegenler Süiti adlı eserinin ortaya çıkışına etki eden unsurlar incelenmiş ve eserin içerdiği sembolizmin müzikal analiz yapılmıştır. Semboller gibi soyut kavramların ve düşüncelerin, eser bestelemede temel müzikal malzeme olması açısından, Gezegenler Süiti oldukça önemli bir örnektir. Söz konusu eserin içindeki sembolizmin ve bu sembolizmin eserin oluşumundaki yerinin incelenmesinin, besteleme yöntemlerinde düşünsel öğelerin yerinin saptanması yönünde önemli olacağı öngörülmektedir.

Anahtar Kelimeler: Holst, Gezegenler Süiti, Sembolizm

\section{ABSTRACT}

Gustav Holst (1874-1934) is an English composer and music educator who was active during the first half of the 20th century. Being influenced by the current musical approaches and socio-cultural conditions of his time, he combined traditional English folk music elements and the symbolic language of various religions and mythologies to create an authentic style. He was a very inspirational figure among his peers and also for future composers. The aim of this article is to research the symbolism which inspired Gustave Holst to compose his milestone work The Planets and to analyze how this symbolism was reflected throughout his work. Discussions on Gustav Holst's life, his musical approach and the elements that impacted it are followed by a musical analysis of all the movements of The Planets, alongside their symbolism. The Planets is a very important example of how abstract concepts like symbols and thoughts can be fundamental musical materials in a composition. It is predicted that an analysis of the symbolism in this work and its role in the creation process will be important in determining the importance of intellectual elements in compositional methods.

Keywords: Holst, The Planets, Symbolism 


\section{EXTENDED ABSTRACT}

English composer Gustav Holst is an important figure in the music of the $20^{\text {th }}$ century. Being influenced by this period in a musical and intellectual sense, he created a modern musical language without cutting ties with tradition. As well as being a composer, he was also a researcher, a trombone player, and a music educator. The great English composer and researcher Ralph Vaughan-Williams was Holst's teacher and lifelong friend (New World Encyclopedia, 2017). Vaughan-Williams was a big influence on Holst's music and the musical experience Holst gained through their researches together on English folk music is reflected in his works.

In addition to traditional music, Holst was also very much interested in Eastern religions and spiritualism. The fundamental inspirations behind most of his works were mythology and astrology, which were fields that made use of symbolic language, and which he had both believed in and researched. In his works (under the influence of mythology), the composer tried to reflect the symbols from relevant myths. The opera Stila, the symphonic poem Indra, and the choral work Rig Veda are examples of Holst's works which were inspired by Indian mythology (New World Encyclopedia, 2017). One of Holst's other fields of interest was astrology (Head, 1983, p. 15). He was so thoroughly interested in astrology that he spent many years researching it. His close friend Alan Leo, who was an astrologist, had a great impact on him. Leo's books and especially "The Art of Synthesis" (Leo, 1912) deeply affected the symbolism on which "The Planets" was founded. Astrology is grounded in characters and symbols from Ancient Greek and Roman mythology. Holst represents these characters and symbols in "The Planets" suite by his usage of instrumentation, specific harmonic language, themes and musical elements appropriate to their meanings. "The Planets" consists of seven movements. All seven planets in the Solar System except Earth are represented musically together with their mythological and astrological symbolisms. This article is a research on Holst's beliefs and intellectual interests that affected and developed his musical approach. In this way, "Theosophical Society" (Campbell, 1980) and the concept of modernism (Arnason, 1998 , p. 102) which were founded at the end of the $19^{\text {th }}$ century are referenced.

The modernist approach that had shaped the art of the $20^{\text {th }}$ century deeply affected this English composer. However, he had his own understanding of modernism (Vaughan-Williams, 1920, p. 181). By not cutting ties with his own national musical traditions and 
reflecting his own thought and belief system in his music, Holst developed an original modernist style.

The article then continues to discuss the symbolical language of "The Planets" and how it was reflected musically, by analyzing the work under separate titles for each movement. The composer lined up the planets in his own way. According to his arrangement, Mars is the first planet and Neptune is the last. This actually symbolizes the path of a person from youth to old age. Mars, the first movement, carries the characteristics of the war god. Whereas in Venus, the second movement, we hear a music with a contrasting character, which symbolizes peace. The third movement represents the winged messenger Mercury. The fourth movement carries the characteristics of the joyful and mighty Jupiter. The fifth movement which has a dark atmosphere characterizes Saturn, which symbolizes old age, law and order, and time. The sixth movement Uranus symbolizes an unpredictable character and is rebellious in nature. Finally, the seventh movement represents the end of a person's journey that started with Mars in the beginning and ends in the afterlife.

The article is divided into separate titles, each of which explains the characteristics of the gods of Roman mythology whose names were given to planets, and their equivalents in Ancient Greek mythology, from which they had originated. This character analysis is followed by a discussion on the explanations of the planets in "The Art of Synthesis", which was an inspiration for "The Planets". In light of this information, the reflection of each planet's symbolism on its relevant movement was analyzed in excerpts.

The fact that Gustav Holst so masterfully represented abstract ideas like symbols in music separates him from many of his colleagues and makes him very special. I believe that analyzing how an intellectual idea generates a musical work, how it is reflected in music, and how it is represented aurally are important in understanding the creative process in composing. I hope that this research draws attention to the possibility that a composer's intellectual world, imagination, and beliefs can come to life through music, and how diverse the resources used in a composition can be. 


\section{Gustav Holst'un Yaşamı}

Asıl adıyla Gustavus Teodore von Holst, 21 Eylül 1874 y1lında İngiltere'nin Cheltenham şehrinde dünyaya gelmiştir. Bu ismi I. Dünya Savaşı sırasında İngiliz toplumunda oluşan Alman karşıtı hassasiyetler üzerine 1918 yılında Gustav Holst olarak değiştirmiştir (New World Encylopedia, 2017). Holst kökleri, annesi tarafindan İngiliz, babası tarafindan ise bugünkü Litvanya ve İsveç’e uzanan bir ailenin üyesidir (Jones, 2013). Babasının babas1 Gustavus Von Holst Riga'l1 bir bestecidir ve orta yaşlarında İngiltere'ye göçmüş ve tanınır bir arp öğretmeni olmuştur (Capell, 1928, s. 1073-1075). İlk müzik eğitimini ailesinden almakla birlikte, Kraliyet Müzik Okulunda eğitim görmüş ve 20 yaşına geldiğinde eserler bestelemeye başlamıştır. Bu okulda öğretmeni olan besteci Ralph Vaughan-Williams ${ }^{1}$ ile hayatının ilerleyen yıllarında arkadaş olmuş ve müziğinden etkilenmiş̧tir. Vaughan-Williams kendisinden, besteciliğinde olduğu kadar iyi bir öğretmen olarak bahseder (Capell, 1928, s. 1073).

Gustav Holst yaşamı boyunca çeşitli kurumlarda müzik öğretmeni, orkestra şefi ve tromboncu olarak görev almıştır. Bu kurumlardan en uzun süreli olan St. Paul Kız Okulu'dur. Bu kurumun öğrenci orkestrası için bestelediği "St. Paul Süiti” (1913) önemli eserleri arasinda yer alır (New World Encylopedia, 2017). Besteci orkestra, askeri bandolar, tiyatro oyunları, vokal, koro, oda müziği, solo piyano gibi bir çok alanda ve türde eserler vermiştir. Eserlerine örnek olarak "Askeri Bando için I. Süit” (1909), "Askeri Bando için II. Süit” (1911), "Gezegenler Süiti” (1918), "Brook Green Süiti” (1933), "Sita Operas1” (1906), "Bulut Habercisi” (1910) gösterilebilir.

\section{Gustav Holst'un Müzikal Anlayışı}

Gustav Holst'un eserleri özde Stravinsky ve Ravel'in stillerini çağrıştırır. Ayrıca Richard Strauss, Grieg, Vaughan-Williams gibi yaşadığı dönemin büyük ustaları da kendisine ilham vermiştir (New World Encylopedia, 2017). Holst çok uluslu bir müzikal malzemeyi kendi iç dünyasından ve sosyal çevresinden gelen düşünsel öğelerle birleştirmeyi de başarmıştır. Bestecinin vardığı nokta kendine özgü bir İngiliz romantizmi olmuştur (Britannica, Gustav Holst, 2018).

Gustav Holst zaman içinde oluşturduğu, bahsi geçen özgün stili ile 20. yüzyılın başında-

1 İngiliz besteci, müzik araştırmacısı (1872-1958) 
ki "modernist besteci" profilini de yansıtır. Bu noktada bestecinin "modernizm" içindeki yerini incelemeden önce dönemin modern kavramını ele alalım.

Genel olarak modern sanat kavramı yaklaşık olarak, 1860'tan 1970 yılına kadar olan dönemin farklı sanat kollarının çoğu sanat eserini kapsar. Bu kavram bu dönemde üretilmiş sanat eserlerinin stil ve felsefesine atıfta bulunur, sanatın tüm alanlarında düşünsel bir katman içerir (Arnason, 1998, s. 102). 20. yüzyıl başı itibarıyla "Modern Hareket" olarak yayılan modern yaklaşım ekspresyonizm, sürrealizm, empresyonizm gibi akımları içine alan geniş bir kavram idi (Head, 1983, s. 15-22). Modern kelimesi bir sanat terimi olarak, çoğunlukla yeni deneyimlere açık bir ruh ile geçmişin geleneğinden bağlarını kopartmış sanat ile de bağlantılı sayılmaktaydı² (Gombrich, 1958, s. 419).

Holst'un yaşadığı döneme ait modernizm anlayışı ise mistik öğeler barındırır. Egzotik ülkelerin kültürlerinden etkilenmiş, Antik dünyanın mitolojisinden beslenen, spiritüel ${ }^{4}$ öğeler içeren bir yapıya sahiptir (Head, 1983, s. 15).

Holst'un kendine özgü bestecilik anlayışına ve modern stiline dair yetkin bir görüşe yakın arkadaşı, hocası ve meslektaşı olan Ralph Vaughan-Williams'ın yazdığı iki makalede rastlıyoruz (Vaughan-Williams, 1920). Vaughan-Williams'a göre Gustav Holst modern bir bestecidir. Ancak modern kavramının kullanımını sorgulamış, bu terimin 19. yüzyılın son çeyreğine ait bestecilerin abartılı yapıtlarının armonik dilinin seyreltilmesinden ibaret bir kavram olarak kullanıldığını ifade etmiştir. Holst ise modern addedilen basmakalıp uygulamalara takılmadan 19. yüzyılın tüm armonik hilelerinden kaçınmaktadır. Bu inceleme-makalede Vaughan-Williams, Holst'un modernizm olarak tanımlanan müzikal klişelerden nasıl kaçındığını ve gerçek modern kavramına nasıl uyum sağladığını şu sözlerle anlatır:

“Holst, birçok çağdaşından neredeyse her sekiz ölçüde bir düzenli olarak Majör 9'lular kullanmaktan kaçınarak, uzun ezgiler kullanmaktan korkmayarak, çoğunlukla bu uzun ezgileri tek başına ya da sade bir armoni ile duyurma cesaretine sahip olarak farklılaşmıştır. O her zaman ihtişamı, çalgılamada sekiz adet korno kullanarak sağlamaz. O etkileyici stilini Bach 'a, Purcell'a, Byrd'a, Wilbye'a borçludur. Bu bileşim bir özgünlük oluşturur ve bu

2 Müzik tarihçilerinin bir kısmı 20. yüzyılda bestelenen müziğin tümünü Modernizm çerçevesinde ele alırken bir diğer kısmı ise 1960 sonrası için post-modernizm terimini kullanır. Ancak ortak çerçevede, 20. yüzyıl müziğinin tamamının, geleneksel uygulamaları yıkmaya çalışırken esin kaynağı olarak geçmiş yüzyılların sanatsal malzemelerinden, başka sanat dallarından ve farklı kültürlerden beslendiğini söyleyebiliriz. (İlyasoğlu, 1999, s. 197)

3 Gizemci

4 Tinsel 
onu gerçek anlamda modern olan birkaç besteciden biri yapar" (Vaughan-Williams, 1920, s. 181).

Bu inceleme-makalede Holst'un etkilendiği öne sürülen besteciler Barok ve Rönesans dönemine ait bestecilerdir. Görülüyor ki Holst gelenek ile bağlarını koparmadan yapıtlarında, düşünsel ve müzikal açıdan modern anlayışa dahil olmayı başarmıştır.

\section{Gustav Holst'un Müziğine Etki Eden Düşünsel, Sosyal ve Kültürel Unsurlar}

Gustav Holst'un müzikal açıdan üretken olduğu 20. yüzyılın ilk çeyreğinde, İngiltere’de eski İngiliz halk şarkıları, madrigal ${ }^{5}$ şarkıcıları ve Tudor dönemi ${ }^{6}$ bestecileri müzik çevrelerinin büyük çoğunluğu tarafindan yeniden ilgi çekici bir sanatsal malzeme haline gelmiştir. Bu geleneksel öğelerin yeniden sanat çevrelerine etki etmesinde 19. yüzyılın sonunda ortaya çıkan ve geniş bir kitlenin ilgisini çeken egzotizm ${ }^{7}$ akımının ve teozofi felsefesinin büyük ölçüde etkisi bulunur.

Egzotizm, 19. yüzyılın ortalarından itibaren Avrupa' da ilgi çeken bir akım haline gelmiştir. Bu akımın ortaya çıkışında ise özellikle Büyük Britanya İmparatorluğu'nun başını çektiği sömürgecilik ve emperyalist kolonileşmenin etkisi büyüktür. Egzotik meraklar sonucunda uzak coğrafyalara ${ }^{8}$, farklı kültürlere, bu kültürlerin mitlerine, masallarına, sembollerine ve antik dünyanın kültürel mirasına ilgi artmıştır. Bu ülkelerin masalları ve kültürü kadar müzikal malzemeleri de besteciler için ilgi çekici olmuştur. Bu dönemde sanat çevrelerinde Hint mitolojisi, Sanskrit dili, Hint kökenli inançlar da ilgiyi üzerine çekmiştir.

Gustav Holst aynı zamanda folklor araştırmacıları da olan meslektaşları Cecil Sharp ve Ralph Vaughan-Williams'ın etkisinde kalarak İngiliz halk şarkılarını incelemiştir. Müziğinde bu ezgilerin etkisi görülür. Bununla birlikte besteci, ilk gençliğinden itibaren doğu felsefesine tutku derecesinde ilgi duymuştur. Sanskritçe öğrenmiş ve çeşitli Hindu sözlerini bestelemiştir (İlyasoğlu, 1999, s. 189).

5 Madrigal özgün yapıda dini olmayan vokal için yazılmış müzikal kompozisyondur. Ortaçağ'da, Rönesans ve Barok dönemde bu türün örneklerine sıklıkla rastlanır.

6 1485-1603 tarihleri arasında İngiltere'de Tudor Hanedanı'nın hüküm sürdüğü dönem. Büyük Britanya İmparatorluğu'nun en parlak dönemlerinden biri olarak kabul edilir.

7 Yabancillık

8 Burada bahsi geçen egzotik coğrafya, Uzakdoğu, Yakındoğu, Hint ve Arap ülkelerini kapsayan tüm Asya ve Afrika kıtalarını içerir (İlyasoğlu, 1999). 
19. yüzyılın ikinci yarısında, bahsi geçen sosyokültürel kaynaklı gelişmelerin etkisiyle oluşan teozofi felsefesi ${ }^{9}$ ise 1875 yılında Helena Blavatsky ${ }^{10}$ tarafından New York'ta kurulan "Teozofi Cemiyeti” etrafında şekillenen yeni bir düşünce ve inanç sistemidir (Campbell, 1980, s. 27-28). Bu cemiyetin sanat çevresinden olduğu kadar bilim ve siyaset alanından da katılımcıları olmuştur. Bu açıdan bakıldığında, "Teozofi Cemiyeti” dönemin popüler kültürünü de etkilemiş bir oluşumdur. Blavatsky’ye göre bu cemiyetin yeni bir din oluşturma gayesi yoktur. Cemiyet, antik dönemlerin bilgeliğini, Platoncu düşünceyi ve tüm semavi dinlerin inançlarını sentezleyen bir teozofi felsefesini savunur (Campbell, 1980, s. 36).

Dönemin kimi İngiliz bestecileri de Holst gibi bu yeni teozofi felsefesinden etkilenmiştir. $\mathrm{Bu}$ bestecilere Edward Elgar, Frederick Delius, Charles Villiers Stanford, Hubert Parry, Ralph Vaughan-Williams ve Arnold Bax’1 örnek gösterebiliriz (Head, 1983, s. 16).

\section{Gezegenler Süitine Genel Bir Bakış, Eserin Ortaya Çıkışına Etki Eden Unsurlar}

Holst'un “Gezegenler Süiti” adlı eseri toplam yedi bölümden oluşur. Schoenberg' in 1914 yılında Londra'da ilk dinletisi gerçekleşen "Orkestra için Beş Parça” adlı eseri, Holst'a eserinin adı ve yapısı konusunda ilham kaynağı olmuştur. Bu sebeple esere Holst tarafindan verilen ilk isim “Büyük Orkestra için Yedi Parça”dır (Lambourn, 1987, s. 425).

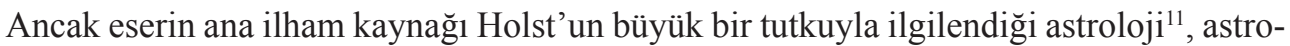
lojinin beslendiği alan olan mitoloji, zaman içinde tanıştığı ve onu etkileyen arkadaşları ile teozofi felsefesinin ona kattıklarıdır (Head, 1983, s. 15).

Holst'un astroloji ile tanışması 1912 yılına dayanır. Bestecinin, Raphael takma isimli astroloğun ilk baskısı 1910 yılında yayınlanan “Dünya Astrolojisi” kitabını okuduktan sonra astrolojiye ilgisi artar ve bu alanda çalışmalarına başlar. Öyle ki bu kitabın etkisiy-

9 Teozofi kelimesinin kökeni Yunanca'dır. Tanrı anlamına gelen teo ve bilgelik anlamına gelen sofia kelimelerinin birleşiminden oluşur. "Varlık birliği”" inancını kapsayan hint teozofisi, Antik dönemin Gnostik ve Yeni Platoncu anlayışı bugünkü Batı teozofisi kavramının temelini oluştursa da günümüzde teozofi kelimesi yaygın olarak Batı teozofisini kapsar. Buna neden 19. Yüzyılda Teozofi Cemiyeti merkezinde filizlenen yeni bir Batı teozofisi felsefesinin oluşmasıdır (Melton, 2015).

10 Elena Petrovna Blavatskaya (Ukrayna 1831 - Londra 1961)

11 Astroloji gökcisimlerinin kişilik, insan ilişkileri ve dünya olayları üzerindeki etkisini anlamaya, yorumlamaya ve bu alanlarda gelecek öngörüleri yapmaya çalışan bir sistem ve inançlar bütünüdür. (Encyclopedia, 2016) 
le, astrolojik doğum haritasındaki ${ }^{12}$ gezegen etkilerine uygun olarak, yeni bir ses dünyas1 keşfetmek üzere doğum haritasından yola çıkarak meditasyonlara ${ }^{13}$ başlar (Head, 1983, s. 17).

1913 yılında prömiyeri yapılan "Bulut Habercisi" adlı eserinin beklediği ilgiyi görmemesi ve başarısız olarak nitelendirilmesi Holst'un hayatında bir dönüm noktası oluşturur. Maddi ve manevi olarak sıkıntılı bir dönem geçirmektedir. Bu olaydan sonra Holst, 1913’te İspanya'nın Mayorka Adası'na bir gezi gerçekleştirir. Bu zamana kadar “Teozofi Cemiyeti"nden edindiği bilgi birikimi ile genel bir astroloji bilgisine sahip olsa da bu gezi süresince Arnold Bax, Bax'ın yazar-çevirmen kardeşi Clifford Bax ve Balfour Gardiner ile yaptığ sohbetler bestecinin astrolojiye bakış açısını genişletmiştir. Ancak Holst için "Gezegenler Süiti”nin ana ilham kaynağı sonradan yakın dost olacağı astrolog Alan Leo'nun (1860-1917) 1912 yılında yayınlanan "Sentez Sanatı"14 isimli kitabı olmuştur. Bu kitapta Alan Leo her gezegeni astrolojideki karşılığını oluşturan mitoloji karakterlerine uygun başlıklarla tanımlamıştır. Bu başlıklar şu şekildedir: "Güneş - Hayat Veren", “Ay - Anne", "Merkür - Düşünür”, "Mars - Enerji Veren”, "Venüs - Birleştiren”, “Jüpiter - Neşelendiren", "Satürn - Hakimiyet Kuran", "Uranüs - Uyandırıcı", "Neptün - Gizemli”. Holst eserinde, bu kitaptaki altı adet başlığın eş anlamlı karşılıklarını kullanmıştır. Neptün'ü ise olduğu gibi kullanmayı tercih etmiştir (Head, 1983, s. 18). Gezegen isimlerini içeren bölüm isimleri eserin 1918 'deki ilk dinletisi için programa eklenmiştir ve bu bölüm adları ve alt başlıkları bu şekilde kullanılır olmuştur. Eserin özgün partisyonunda bölüm adları sadece "Savaşı Getiren”, "Barışı Getiren” gibi aşağıda adı geçen mevcut alt başlıklardan oluşur. Holst gezegenimiz olan Dünya'yı bu esere dahil etmemiştir ${ }^{15}$. Eserdeki bölümler ve alt başlıkları şu şekildedir:

\section{Mars - Savaş1 Getiren (1914) \\ 2. Venüs - Barışı Getiren (1914) \\ 3. Merkür - Kanatlı Ulak (1916)}

12 Doğum haritası (horoskop), astrolojik yorumlar için kullanılan ve kişinin doğduğu ya da bir olayın olduğu an ve yere göre hazırlanmış, o anın mevcut gökyüzünün dünyaya izdüşümünü gösteren ilgili haritadır. (Britannica, Horoscope, 2008)

13 Dini inanışlardan bağımsız olarak, zihni bir noktaya odaklayarak sakinleşme ve gevşeme eylemi. (https://www. merriam-webster.com/dictionary/meditation)

14 Özgün İngilizce adı ile 'The Art of Synthesis'

15 Eser bestelendiği dönemde Plüton henüz keşfedilmemiştir. Ancak Holst ölmeden önce Plüton'un 1930 yılındaki keşfine tanık olduysa da onu bu esere dahil etmeyi düşünmemiştir. Plüton, 2006 yılında Uluslararası Astronomi Birliği tarafından, yeniden belirlenen kriterlere göre gezegen sınıfından çıkartılmıştır. 
4. Jüpiter - Neşeyi Getiren (1914)

5. Satürn - Yaşl1llı̆̆ Getiren (1915)

6. Uranüs - Büyücü (1915)

7. Neptün - Gizemli (1915)

Holst eseri kalabalık bir orkestra için tasarlamıştır. Eseri icra edecek orkestra şu şekildedir: dört flüt, üç obua, bir korangle, üç klarnet, bir bas klarnet, üç fagot, iki kontrafagot, altı korno, dört trompet, iki tenor trombon, bir bas trombon, bir tenor tuba, bir bas tuba, altı timpani, bir triangle, bir davul, bir tef, bir zil, bir büyük davul, bir gong, bir çan, bir glockenspiel, bir çelesta, bir ksilofon, iki arp, bir org, yaylı sazlar ve kadınlar korosu (sadece yedinci bölümde kullanmak üzere).

\section{Mitolojik Sembolizmin Gezegenler Süitindeki Yansımaları, Eserin İçerdiği Sembolik Dilin İncelenmesi}

Holst'un eserde gezegenleri sıralama şekli yer merkezli ${ }^{16}$ ya da gün merkezli ${ }^{17}$ iki modele de uygun değildir. Besteci burada özgün bir sıralamayı tercih etmiştir. 1927 yılında bu s1ralamayı astrolojik bir nedene dayanarak, "kaderimizin yedi etkisi ve ruhumuzun yedi bileşenine" karşı1ık olarak yaptığını belirtmiş̦tir. Gezegenlerin bu sırası, gençlikten yaşl1lığa doğru ilerlerken yaşamın ilerleyişini tasvir eder (Head, 1983, s. 19). Gezegenlerin temsil ettiği sembolizmi incelediğimiz zaman, bu sıranın aynı zamanda gençliğin dinamizminden yaşl1lığın bilgeliğine, dünyevi olandan ruhani ve ebedi olana doğru bir yolculuğu temsil ettiğini görmüş olacağız. Şimdi eserde kullanılan sembolizmi, eserin bölümleri altında inceleyelim.

\section{Birinci Bölüm: Mars - Savașı Getiren}

Eserin birinci bölümüne adını veren Mars karakteri, Roma mitolojisinde Jüpiter ve Juno'nun oğludur. Roma mitolojisinin kökleri Antik Yunan mitolojisine dayanır. Karakterler ve hikayeleri benzer olmakla birlikte isimler değişmiş̧ir (Luce, 2005, s. 202). Mars karakterinin Antik Yunan mitolojisindeki kökeni Ares’tir. Karakter her iki mitolojide de aynı tasvire sahiptir ve savaş tanrısıdır (Perowne, 1969, s. 19). Bu mitolojik karakter tarımın ve savaş hazırlıklarının canlandığı, baharın başlangıcı olan mart ayına da adını

16 Eş anlamlısı jeosantrik olan ve Dünya merkezinden bakılarak ölçülen mesafe şekline atfedilen astronomi terimi.

17 Eş anlamlısı helyosantrik olan Güneşin merkezinden bakılarak ölçülen mesafe şekline atfedilen astronomi terimi. 
vermiştir (Mary Beard, 1998, s. 47-48). Mars karakteri Yunan kökeninde yabanıl, iri vücutlu olarak tasvir edilmiştir. Savaş alanına indiğinde korkutucu naralar atar. Sesi açısından heybetli ve ürkütücüdür. Tepeden tırnağa zırh ile kuşanır. Daima silahlıdır. Hayvansı iç güdüleri, mantıksız ve ihtiyatsız davranışları vardır. Bu yönüyle çoğu zaman zeki davranışları olan diğer tanrısal güçlere yenik düşer (Agizza, 2006, s. 63). Düzene karşı gelmek ister, yasaları ve mahkemeleri tümden hiçe sayar (Agizza, 2006, s. 64).

Astrolog Alan Leo'nun "Sentez Sanatı" kitabında ise Mars gezegenine atfen "enerji veren", “yıkıcı melek" tasvirleri kullanılmıştır (Leo, 1912, s. xiv). Bu gezegen mitolojideki gibi astrolojik sembolizminde de bağımsız ve öncü bir ruhu, cesareti, yiğitliği, özgürlüğe olan aşk1, liderlik edebilme kapasitesini, organizasyon becerisini taşır (Leo, 1912, s. 78). Doğası gereği harekete geçen, öfkeli bir kişiyi ayrıca kesici maddeleri, cerrahiyi, savaşı, istediğini elde etme güdüsünü, kan ve kırmızı rengi temsil eder. Ayrıca Mars karakteri, Antik Yunan mitolojisinden farklı olarak, Roma mitolojisinde Picus adlı bir ağaçkakan ${ }^{18}$ tarafından kutsanmıştır (Rosivach, 1983, s. 520).

Şimdi bahsi geçen bu semboller doğrultusunda söz konusu eserin "Mars - Savaşı Getiren” bölümünü inceleyelim.

Ağaçkakan sembolü: Eserin bu bölümü yaylılar ve timpaninin duyurduğu bir ostinato $^{19}$ ile başlar. 5/4 lük aksak ölçülü bir ostinato motifi ilk 60 ölçü boyunca durmadan devam eder. Eserin bu bölümünün büyük bir kısmında da duyulur. Yaylılar ve timpani çoğu zaman birlikte aynı ritmik yürüyüşü sürdürürler. Bu yürüyüsse zaman zaman diğer çalg1lardan da katılanlar olur. Bu ritim bir ağaçkakanın gagasını ağaçlara vurarak çıarttığı 1srarlı ritmi çağrıştırır. Besteci timpaninin 60. ölçüye kadar ahşap malet ile icrasını istemiştir. Bununla birlikte ilk 25 ölçü tüm yaylıların col legno ${ }^{20}$ olarak çalması da ağaca ısrarlı ritmik gaga darbeleri yapan ağaçkakan tınısını pekiştirir.

18 Yunan düşünür ve devlet adamı Plütarkos’a göre (m.s 46-120) Roma'l1lar kurucuları olan Romus ve Romulus adlı kurtlara yol gösterdiği ve Mars’ı kutsayan için Picus adlı ağaçkakandan ötürü bu kuşa saygı gösterir ve ondan çekinirler. (Plütarkos, 2013, s. 74)

19 Genellikle dar bir ses alanı ya da aynı ses üzerinde sürekli tekrarlanan motif ve müzik cümlesi.

20 Yaylı çalgılarda arşenin ahşap kısmı ile icra yöntemi. 


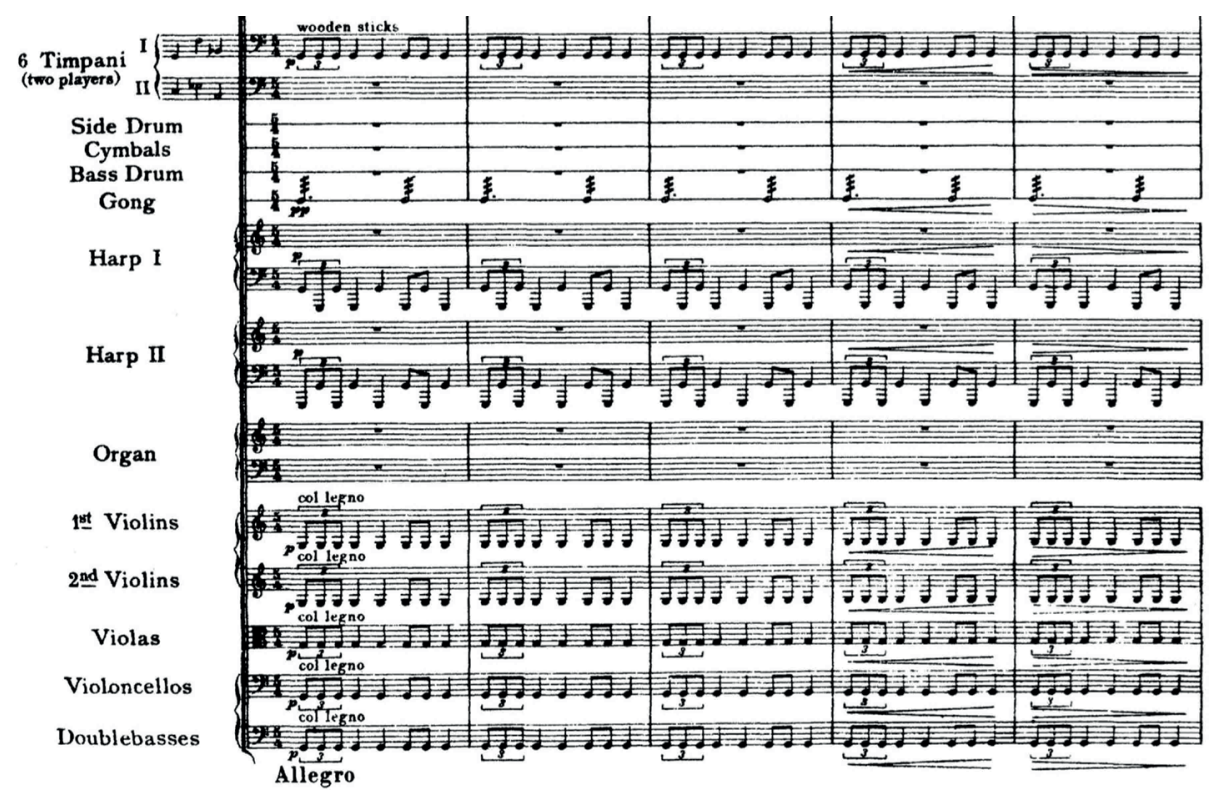

Şekil 1: Gustav Holst, Gezegenler Süiti I. Bölüm, Mars - Savaş1 Getiren, 1-6 ölçüler aras1

Demir, mızrak, zırh, kılıç: Bölüm boyunca kullanılan büyük orkestranın sayıca fazla bakır çalgıları Mars karakterinin metal, demir, maden ile ilintili sembolizmini fazlaca çağrıştırır.

Asker yürüyüşü: İlk ölçüden 60. ölçüye kadar tekrarlanan ostinatolu yürüyüş bir askeri taburun yürüyüşü çağrıştırır. 


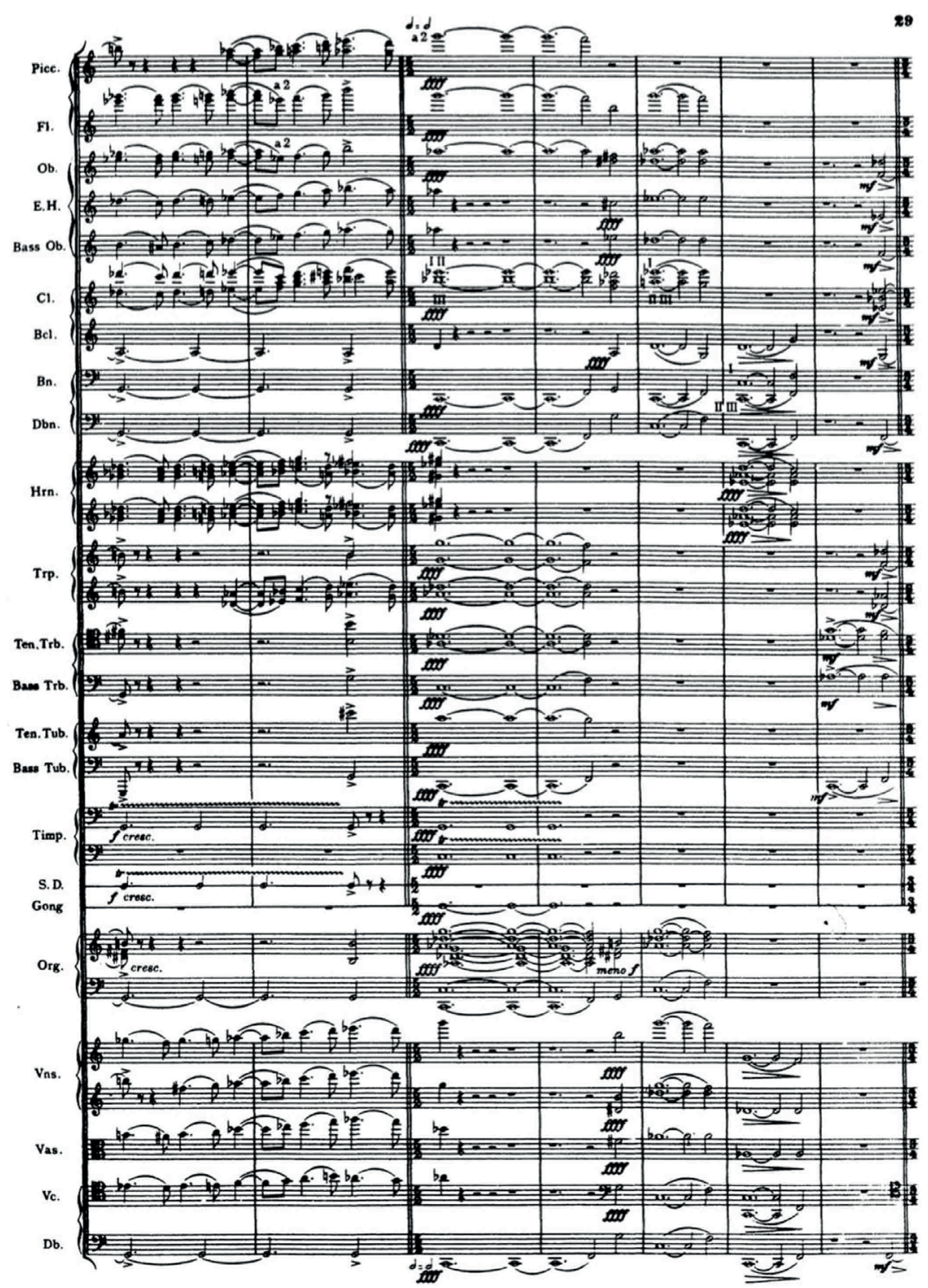

Şekil 2: Gustav Holst, Gezegenler Süiti 1. Bölüm, Mars - Savaşı Getiren, 183. ölçüde orkestranın tutti olarak $^{21}$ ffff ses gürlüğüne ulaşması

Öfke, Bağırmak, Savaş Naraları: Orkestranın sayıca fazla bakır çalgılar ile büyük bir ses yoğunluğuna sahip olması, giderek artan bir kreșendonun sonunda 183. ölçüde tutti ${ }^{22}$

21 Tüm orkestranın aynı anda çalması

22 Tüm orkestranın aynı anda çalması anlamına gelen müzik terimi. 
olarak ffff ses gürlüğüne ulaşması Mars'ın öfkesini, savaş alanında attı̆̆ı naraları ve hiddetle bağırmasını çağrıştırır.

Özgürlük, başkaldırı, düzene karşı gelmek, yıkıc1lık: Bölümün 5/4'lük ve 5/2'lik aksak ölçülerle yazılması Mars karakterinin özgür, düzen bozucu, kimi zaman mantıksız ve güdüsel davranan yönünü hissettirir. Ayrıca bu bölümde kullanılan dörtlüler armonisi ${ }^{23}$ de çok sesliliğin uyumluluk esasına, bir başka deyişle armoni yasalarına başkaldırı olarak değerlendirilebilir. Bu durum, Alan Leo'nun Mars için kullandığ 1 yıkıcı melek tasvirine ve mitolojik anlamda bakıldığında güdülerine yenilerek yıkıcı davranan ve yasaları hiçe sayan Mars karakterine uyumlu bir ses dünyasını oluşturur (Head, 1983, s. 19).

\section{İkinci Bölüm: Venüs - Barışı Getiren}

Eserin ikinci bölümüne adını veren Venüs, Antik Yunan mitolojisindeki aşk tanrıçası Afrodit karakterinin Roma mitolojisindeki karşıllı̆ıdır (Wolfson, 2002, s. 45). Venüs karakterinde Akdeniz'in önemli yeri vardır. Babası Ouranos'un ${ }^{24}$ Kıbrıs'ın sularına atılan uzvundan türemiştir. Burada deniz suyunun köpüklerinden doğarak can bulduğu söylenir (Agizza, 2006, s. 71). Her iki mitolojide de güzellik, aşk, şarap tanrıçasıdır. Yaşam isteğini, yaşamdan alınan tatları, arzuları temsil eder. Aynı zamanda karşı1ıklı uyumun, huzur ve barışın tanrıçasıdır. Bahçeler, çiçekler, güzel kokular, keyif veren her şey onun simgesidir.

Alan Leo'nun "Sentez Sanatı" kitabında Venüs’ten "birleştiren” olarak bahsetmiştir. Bu bağlamda iyicil bir niteliği vardır. Ona göre Mars hayvani güdülerimiz ise Venüs insancıl tarafımızdır. Mars dünya ile Venüs ise cennet ile ilintilidir. Tüm güzel, çekici nesneler, düşünceler, arzularımız, iştah, zarafet, huzur Venüs'ün temsil ettiği konulardır. Ayrıca aşık olunası ideal, mükemmel, kusursuz yaradılışı simgeler. Aynı zamanda sanatın temsilcisidir. Başta uyumlu, güzel sesler, müzik olmak üzere tüm güzel sanatları kapsar (Leo, 1912, s. 66). Leo'ya göre Venüs, düzenli ilerleyen uyumlu hareketin de yaratıcıs1dir (Leo, 1912, s. 69).

Bahsi geçen bu semboller ışığında söz konusu eserin ikinci bölümünü inceleyelim.

Huzur ve uyum: Bu bölümde, ilk bölümde duyurulan kaotik savaş tasvirinin ardından

23 Doğuşkanlardan türeyen ve üçlü aralıklar ile oluşan akorlardan oluşan bir çok seslilik anlayışının tersine, dörtlü aralıkları esas alan çok seslilik anlayışına atfedilen müzik terimi.

24 Ouranos'un Roma mitolojisinde karşılı̆̆ 1 yoktur. 
gelen bir barışı hissederiz. Eserin bu bölümü "Venüs - Barışı Getiren" başlığını taşır. ${ }^{25}$ Ve bu bölüm Mars (savaş) ile Venüs (barış, huzur) karakterlerinin tezatlığını da yansıtır. İlk bölümdeki "Allegro" yüksek tempo yerini, bu bölümde “Adagio" olarak dingin bir tempoya birakır.

İlk bölümdeki dörtlüler armonisi yerini uyumlu üçlüler armonisine bırakmıştır.

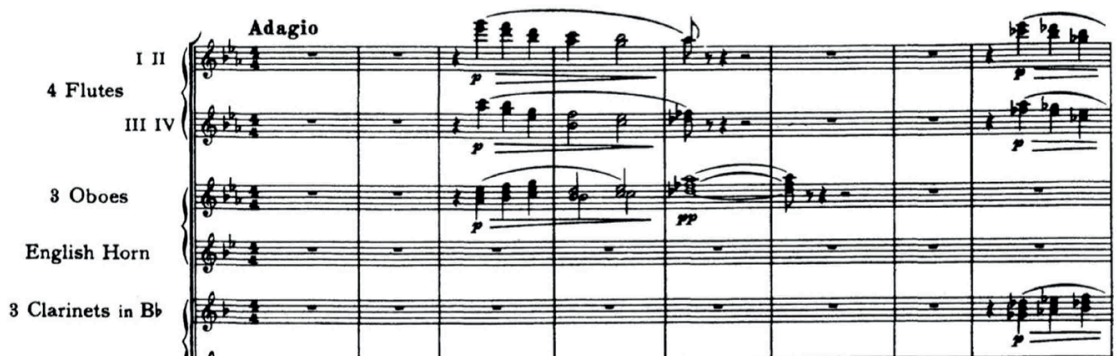

Şekil 3: Eserin ilk 8 ölçüsü boyunca flüt, obua ve klarnet partilerinde duyulan kök pozisyonda 5'li akorlar

İlk bölüm olan "Mars - Savaşı Getiren"in aksine bu bölüm boyunca $p$ ve $p p$ ses gürlüğü hakimdir. $\mathrm{Bu}$ da bölümün huzurlu atmosferini pekiştirir. Bununla birlikte ilk bölümdeki ölçüsel düzensizlik ${ }^{26}$ de bu bölümde yerini iki, üç ve dört zamanlı basit ölçü tiplerine bırakmıştır. Tüm bu öğeler tıpkı bir savaşın ardından gelen barış gibi ilk bölümün dinamik, gergin, savaşçı atmosferinin ardından gelen yoğun bir huzuru hissettirir.

Bu bölümdeki dingin atmosfer, aşağı ve yukarı yönde melodik hareketlere duyulan tam 5'li aralıkların oluşturduğu durağan ve çözülme hissi uyandırmayan bir armoni ile pekiştirilmiştir (Head, 1983, s. 19).

Doğa ve pastoral atmosfer: Bölümün başında kornoların çıkıcı, obua ve flütlerin inici olarak duyurduğu iç içe geçmiş motifler bütünü pastoral bir atmosfer oluşturur.

Cennet, 1rmaklar, çeşmeler: Bölümün 11. ölçüsünde duyulmaya başlayan arp pasajı mitolojik tasvirlerdeki meleklerin lirini çağrıştıran bir atmosferi oluşturur. Ardından duyulmaya başlayan ve arplara eşlik eden glockenspiel ve çelestalar cennetin huzurunu, çağlayan ırmakları çağrıştırır.

25 Bestecinin bölüme verdiği başlığı incelerken İngilizce "peace” kelimesinin aynı zamanda huzur anlamına geldiğini de göz önünde bulundurmalıyı.

26 İlk bölüm olan 'Mars - Savaşı Getiren' 5 zamanlı aksak ölçü birimi ile yazılmıştır. 5 zamanlı ölçüler, ölçü içindeki zamanların hem ikiye hem üçe bölündüğü düzensiz ölçü birimleridir. 
Güzel sanatların dalı olarak müzik ve şarkı: Venüs'ün temsil ettiği müzik, şarkı söylemek, güzel ses kavramları, bölümün 32. ölçüsünden itibaren duymaya başladığımız solo kemanın lirik teması çağrıştırır. Bu tema 37. ölçüde tutti ile devam etse de 60 ve 65 . ölçüler arasında yine solo olarak kendini duyurur.

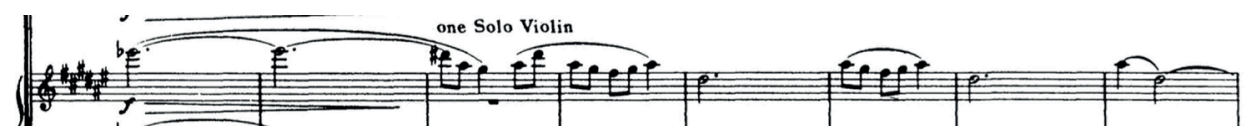

Şekil 4: Eserin ikinci bölümünde 60-65. ölçüler arasında solo keman ile duyurulan lirik tema

\section{Üçüncü Bölüm: Merkür - Kanatlı Ulak}

Roma mitolojisinde Merkür'ün kökeni Antik Yunan mitolojisindeki Hermes'e dayanır. Her iki mitolojide de Merkür, kanatlı ayakkabıları ile tanrıların habercisi ve mesaj taş1yan elçisidir. Merkür refah, mutluluk, çocuksuluk ve iyi niyeti simgeler (Cotterell, 1996, s. 61). Aynı zamanda sevimli ve şakacı bir karakter de taşır. Antik Yunan'daki kökeninde ise hırsız ve müzisyen özelliklerine de rastlarız (Agizza, 2006, s. 58). Bu karakter yolda bulduğu bir kaplumbağanın kabuğuna öldürülmüş hayvanların bağırsaklarından elde edilmiş teller takarak lir çalgısını icat etmiştir (Agizza, 2006, s. 61).

Alan Leo'nın "Sentez Sanatı" isimli kitabında bu mitolojik karakterin astrolojideki karş11ığını "Merkür - Düşünür" başlığı altında buluruz (Leo, 1912, s. 53). Mitolojik karakterin bu kitaptaki yansıması, Roma ve Antik Yunan mitolojisindeki karşlığına benzer ifadelerle yer bulmuştur. Ancak Alan Leo Merkür'ü "Doğumu Nasıl Yorumlamalı" adlı kitabında "Kanatlı Ulak" olarak betimlemiştir. Bu başlık, Holst'un eserinin üçüncü bölümüne verdiği isim ile bire bir aynıdır (Head, 1983, s. 19). Bu karakter hızlı ve keskin bir zekayı, hızlı gelişmeleri ve değişkenliği de temsil eder (Leo, 1912, s. 57).

Holst üçüncü bölüme adını veren bu mitolojik karakterin niteliklerini eserin diğer tüm bölümlerinde olduğu gibi astrolojik karşılığını da yansıtacak şekilde işlemiştir. Bu bölümü bahsi geçen nitelikler üzerinden inceleyelim.

Şakac1, muzip: Gustav Holst eserin bu bölümünü scherzando ${ }^{27}$ bir karakterde 6/8'lik ölçüde hızlı bir tempoda bestelemiştir. Ancak bölüm boyunca sıklıkla hemiolalar ${ }^{28}$ duyulur. $\mathrm{Bu}$ durum müziğe eğlenceli bir dans havası verir. Ayrıca iki zamanlı bileşik ölçüler

27 Şakacı, oyuncu bir ifadede anlamına gelen müzik terimi.

28 Bir veya birden çok zamanın aynı anda hem ikiye hem üçe bölünmesi ile oluşan ritmik kalıp . 
ile kurgulanmış bölümde, üçerli ve düzenli olarak gruplanmış sekizlik notaların zaman zaman 3/4'lük ölçü gibi hissettirecek şekilde ikişerli gruplanışı müziğe şaşırtıcı, muzip, şakacı bir ifade vermektedir. Bölüm boyunca yaylı ve nefesli çalgılarda duyulan staccatolar da muzip, şakacı havayı destekler.

Kanatlı ayakkabılar ile göğe yükseliş, göklerde süzülürcesine gezinmek: Bölümün başlığını oluşturan “Merkür Kanatlı Ulak” ifadesi bölüm boyunca çıkıcı ve inici arpejlerle ve çıkıcı dörtleme ritminden oluşan yanaşık sesler ile tasvir edilir. Hızlı tempoda duyulan bu motifler göklerde süzülüyor hissi veren tatlı melodik çizgiler oluşturur. Arpejler ve dörtlemelerin olduğu pasajlarda kullanılan ses bölgesi kalın oktavlardan ince oktavlara ya da tam tersi olarak bir genişleme göstermiştir. Bu durum müziğin yükselmesi ve alçalması duygusunu beraberinde getirir ve dinleyende yer ile gök arasında bir mesafenin kat edilmesi hissini uyandırır.

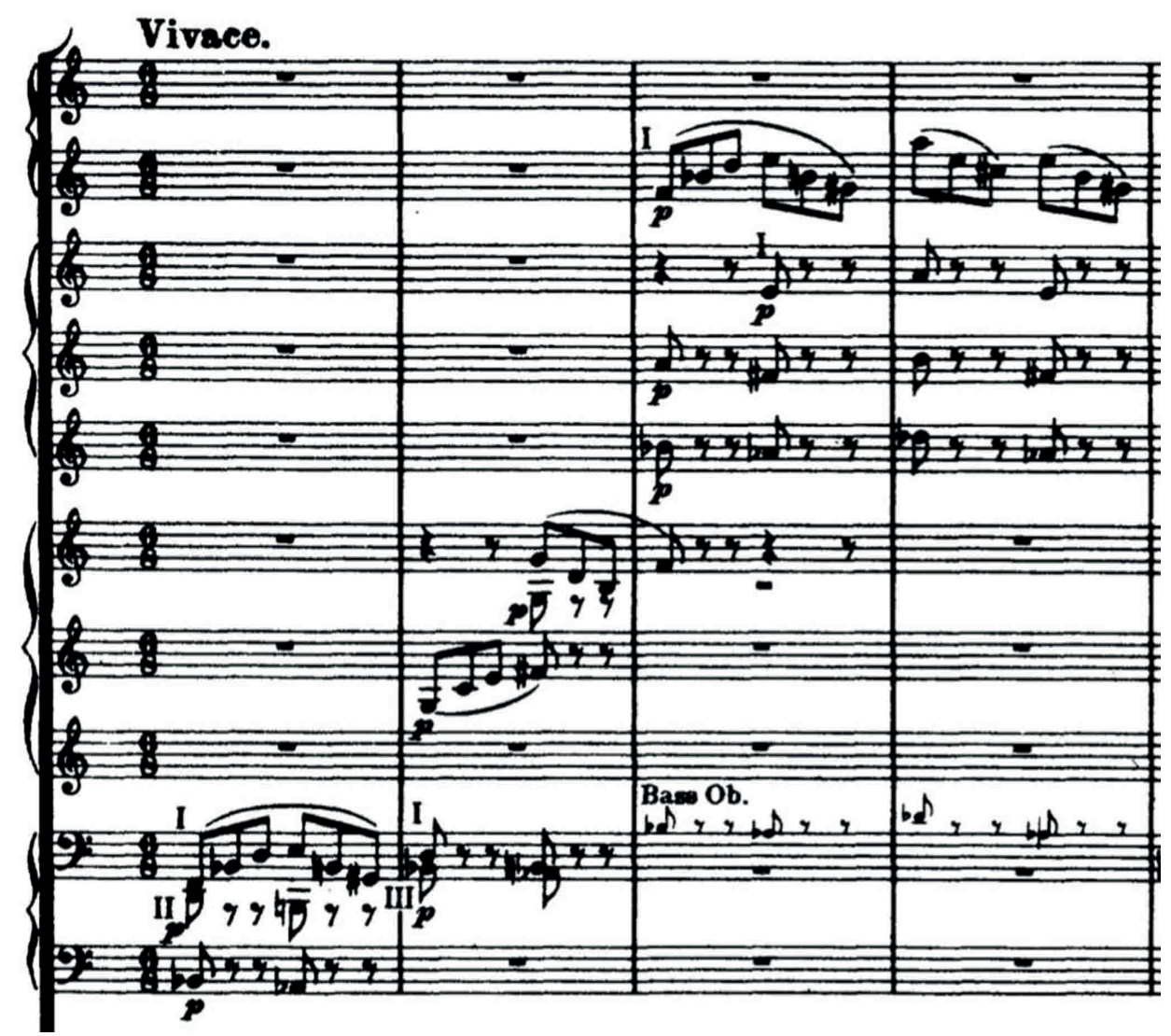

Şekil 5: Kalın ses bölgesinde başlayıp ince ses bölgesine doğru hareket eden çıkıcı ve inici arpejler 


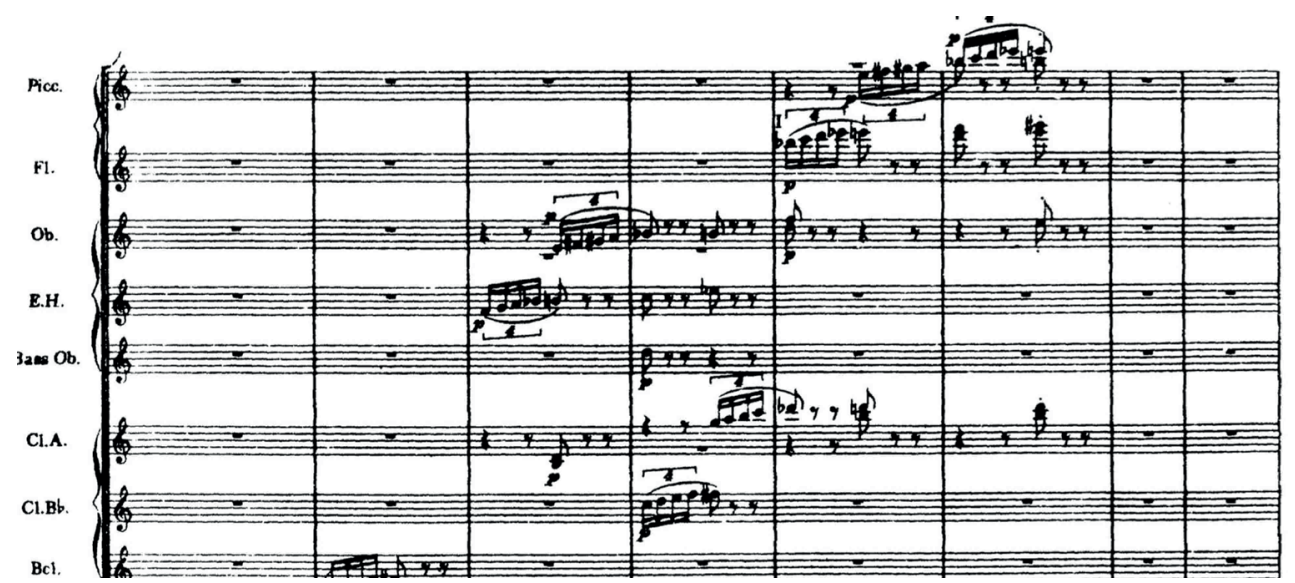

Şekil 6: Çıkıcı ilerleyen dörtlemeler

Müzisyen yönü ile Merkür: Müzisyen olarak nitelenen Merkür karakterinin bu yönünü neşeli ve ritmik yapı açısından şaşırtıcı (üç zamanlı ve iki zamanlı olarak kurgulanmış ölçülerden oluşan) bir melodiye sahip olan solo keman partisinde görürüz. Bölümün devamında bu temayı diğer çalgılar da duyururlar. Besteci Venüs’ün şarkı ve müzik ile olan ilintisini de aynı şekilde bir önceki bölümde lirik bir melodiye sahip keman partisi ile vurgulamış idi. Bu iki bölümde duyulan keman sololar adeta karakterlerin sahneye çıkması gibi yorumlanabilir. İlk bölümdeki keman solosunun melodisi yavaş ve lirik iken bu bölümde canlı bir tempoda ve şakacı karakterdedir.

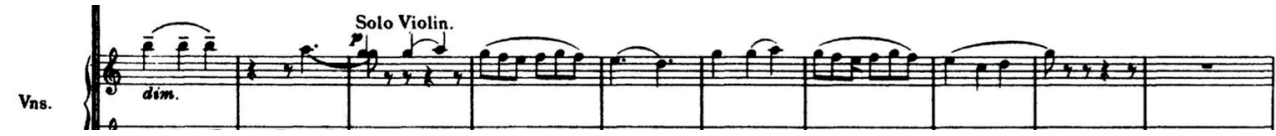

Şekil 7: Üçüncü bölümde 82- 88. ölçüler arasında duyulan keman solosu

\section{Dördüncü Bölüm: Jüpiter - Neşelendiren}

Eserin dördüncü bölümüne adını veren Jüpiter'in Antik Yunan mitolojisindeki kökeni Zeus'tur (Wolfson, 2002, s. 21). Her iki mitolojide de en güçlü, en egemen, en bilge ve en başta gelen liderdir. Kendi kurduğu bir saltanata sahiptir. Adil, zeki, 1şık saçan, gerçekleri simgeleyen dürüst bir mitolojik karakterdir. Yargılama gücünü elinde bulundurur (Agizza, 2006, s. 31). Özellikle Roma mitolojisinde halkın koruyucusu olmuş ve savaşlarda yardım ettiğine inanılmıştır. Yıldırımlar ve fırtınalar oluşturması öfkelendiğinde başvurduğu cezalandırma yöntemlerinden bazılarıdır. (Cotterell, 1996, s. 56). 
Alan Leo’nun “Sentez Sanatı” kitabında bu karakterin astrolojideki karşılığını "Neşelendiren" başlı̆̆ 1 altında incelemiştir. Bu kitapta Jüpiter mitolojik kökenine bağlı olarak, büyük talihin göstergesi olup büyümeyi, genişlemeyi, dengeli bir uyumu, neşeyi, ümidi, asaleti, bilgeliği ve geleceğe dair olumlu inançları temsil eder (Leo, 1912, s. 80). Leo'nun Jüpiter'i "Neşelendiren” olarak tanımlaması gezegenin mitolojik olarak temsil ettiği tüm bu olumlu, mutluluk getiren adil ve destekleyici özelliklerinden ötürüdür (Head, 1983, s. 20).

Bu bilgiler 1şığında eserin dördüncü bölümünde bestecinin Jüpiter karakterini nasıl yansıttığını inceleyelim.

İhtişam, asalet, kraliyet: Eserin bu bölümü kullanılan çalgılama ve armonik dil nedeniyle ihtişam, azamet ve asaleti çağrıştırır. Yaylıların enerjik eşliğinde kornoların duyurduğu ve ardından diğer bakır çalgıların katıldığı tema ise bölüme yine ihtişamlı bir açılış getirir.

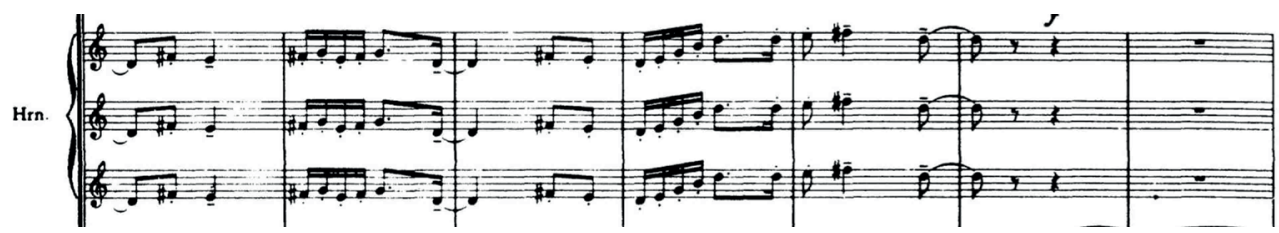

Şekil 8: Eserin "Jüpiter - Neşeyi Getiren” adlı üçüncü bölümünün başlangıcında kornoların duyurduğu tema

Bölüm boyunca bakır çalgıların temaları duyurması ve tüm orkestranın birlikte çaldığıfff pasajlar güç ve ihtişamı pekiştirir.

Bununla birlikte ilk olarak 28. ölçüden itibaren duyulmaya başlayan ve kraliyet tören borusunu çağrıştıran motifler bölüm boyunca tekrarlı olarak karşımıza çıkar. Bu tam dörtlü aralıklardan oluşan motifler adeta kralın gelişini haber veren tören boruları gibidir. Bölüm boyunca temaların arasında bir köprü olarak duyulurlar. Bir başka deyişle bu motifler kraliyetin üyelerini sahneye davet eden bir tören borusu gibidir.

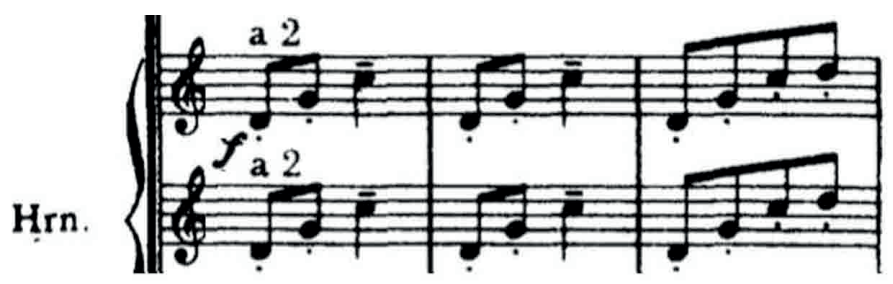

Şekil 9: Eserin dördüncü bölümü 29 - 31 ölçüler arası, tam 4'lü aralıklardan oluşan ve tören borusunu çağrıştıran motifler. 
Neşeli, iyimser: Gustav Holst ise bu gezegeni betimlediği dördüncü bölüme, Alan Leo'nun başlığgnın bir benzeri olarak "Neşeyi Getiren” ismini vermiştir. Besteci bu bölümün başında şakacı, eğlenceli bir yürük tempoyu hedeflemiş ve bu anlama gelen $\mathrm{Al}$ legro Giocoso terimini kullanmıştır. 23. ölçüden itibaren duyulmaya başlayan, kimi zaman timpanilere eşlik eden triangle ve ziller neşeli havayı pekiştirir. Eserde bakırların duyurduğu ikinci baskın tema 47. ölçüde başlar. Bu tema neşeli bir dans karakterindedir. Adeta bir kutlama havası hissedilir.

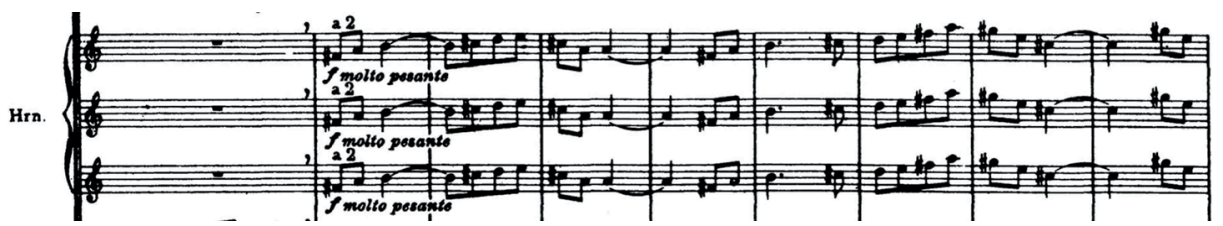

Şekil 10: Eserin dördüncü bölümünde, 68 ve 74. ölçüler arasındaki tema

İnanç ve ümit dolu: Bölümün 195. ölçüsünden itibaren duyulmaya başlayan tema ${ }^{29}$ geleneksel İngiliz halk şarkılarını andırır. Ortaçağ ses dizilerinden Eolien modu $u^{30}$ ile yazılmıştır. Geçmişin müzikal geleneğine bağlı bu tema, ulusalcı bir mesaj içerir. Bölümün yazıldığı dönemde Jüpiter karakteri, monarşi ile yönetilen İngiltere'de kraliyetin gücünü de çağrıştırır. Bölümdeki bu tema, İngiliz halkının asırlar süren öyküsünü betimlerken, mevcut geleneğin sürekliliğini ve geçmişten geleceğe aktarılacağına dair inanç ve ümidi hissettirir.

\section{Beşinci Bölüm: Satürn - Yaşlılığı Getiren}

Antik Yunan mitolojisindeki karşılığı Kronos olan Satürn zamanın efendisidir. Satürn, Jüpiter ile birlikte Neptün, Plüto, Juno, Ceres ve Vesta'nın da babasıdır (Cotterell, 1996, s. 33). Karakter, Antik Yunan'daki kökeninde babası Ouranos'un uzvunu bir orak ile kesmiş olduğundan (Agizza, 2006, s. 20) gerek Yunan gerekse Roma mitolojisinde elinde orak ile betimlenir. Romalılar Satürn'ü hasat tanrısı olarak da betimlemişlerdir. Bu mitolojik karakterin diğer özellikleri arasında, zaman ile birlikte yaşlılığı getirmesi ve Antik Yunan'daki kökeninden ötürü cezalandırıcı olması bulunur.

Alan Leo'nun “Sentez Sanatı” kitabında ise Satürn'den "her şeye hakim olan” başlığı altında bahsedilir (Leo, 1912, s. 88). Burada Satürn hayatımız boyunca, gerçek ile gerçek olmayan, öznel ile nesnel, 1şık ile karanlık, doğru ile yalan ve iyilik ile kötülük arasındaki ilerleyişimiz-

$29 \mathrm{Bu}$ tema daha sonra, 1921 yılında besteci tarafından Cecil Spring Rice’ın şiirine uyarlanmış ve İngilizler için adeta ulusal bir marşa dönüşmüştür (Head, 1983, s. 20).

$30 \mathrm{Bu}$ ses dizisi, tonal sistemdeki doğal minör gama denk gelir. 
de belirleyici, kritik bir aşamayı temsil eder. Leo'ya göre hiç şüphesiz Satürn’ün kötücül bir yönü vardır. Ancak onun bu kötücül yönü kişiyi terbiye etmek üzere olan edimlerindedir. Satürn kişiyi kısıtlar, arılaştırır, yontar ve tüm bunları zamana yayar. Zira zaman en iyi öğretmendir. Orak sembolizmi ile paralel olarak Satürn aynı zamanda ektiklerin biçilmesini, hayattaki hasatları temsil eder (Leo, 1912, s. 88). Ayrıca kişiye kısıtlamalar, sınırlamalar, kasvet ve verilen dersin alınamaması durumunda acı ve keder getirebilir (Leo, 1912, s. 92).

Gustav Holst eserinin beşinci bölümünde Satürn karakterini tüm bu sembolizme bağl1 kalarak betimlemiştir.

Zaman: Holst, eserin bu bölümünde Satürn’ün gelişini bir saatin tik-taklarını çağrıştıran ve temalara eşlik eden senkoplu $u^{3 l}$ bir ritmik ilerleyiş ile duyurarak betimlemiştir. Bu ritmik ilerleyiş eser boyunca aralıklı olarak kendini gösterir.

Harp I

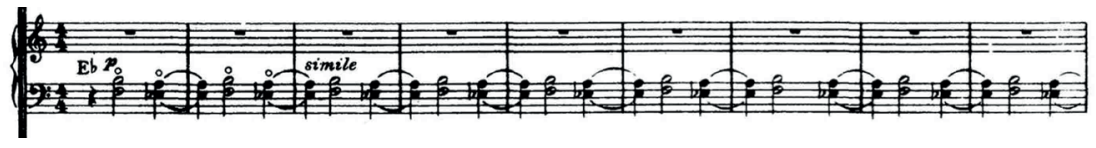

Şekil 11: Eserin dördüncü bölümünde, arp partisinde bir saatin tik-tak'larını temsil eden senkoplu ritm

Kasvet: Bölüm Jüpiter'in neşesi ve coşkusundan sonra ürkütücü ve kasvetli bir hava taşır. Özellikle bölümün hemen başında kontrbas tarafından duyurulan tema Satürn'ün karanlığını ve kasvetini temsil eder. Besteci kullandığg karanlık armonik dil ve bas flüt, bas obua, bas klarnetten oluşan kalın ses perdesinden tahta üflemeli çalgıların karanlık tonları ile bu kasvetli havayı pekiştirir.

Doublebasses

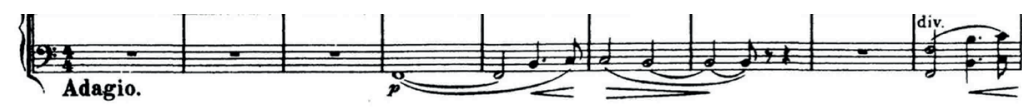

Şekil 12: Bölümün başlangıcında kontrbas partisinin duyurduğu Satürn teması

Yaşlılık: Oldukça yavaş bir tempo ile yazılmış olan bölüm ağır ilerleyişiyle yaşlılığın getirdiği hantallı̆̆ı çağrıştırır.

Kötücül ve şeytani yön: Bölüm içinde çokça duyulan ve tarihsel süreçte şeytan aralığ1 olarak nitelenmiş artmış 4'lü aralığından ${ }^{32}$ oluşan fraz ${ }^{33}$ ve akorlar, bu aralığın yaptığ 1 simgesel çağrışım ile Satürn’ün şeytani ve kötücül yönüne atıf yapar.

31 Zayıf zamanın vurgulanması ile oluşan aksak ritm kalıbı

32 Diabolus in musica 'şeytan aralığı' olarak tabir edilen, üç tondan oluşan +4'lü aralığına atfedilen tarihsel terim. 33 Bir müzik cümlesinin, en az bir motif barındıran bileşeni. 
Bass $\mathrm{Ob}$.

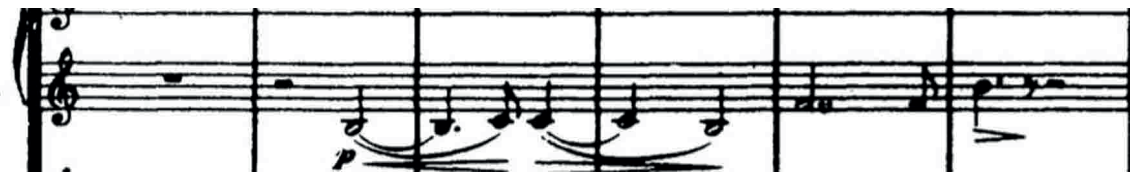

Şekil 13: Dördüncü bölümde, bas obua tarafından duyurulan ve artmış 4'lü aralığından oluşan karanlık tema

Cl.

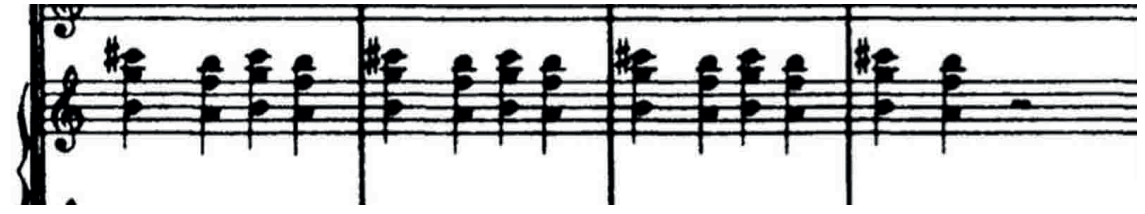

Şekil 14: Dördüncü bölümde klarnetlerin duyurduğu artmış dörtlü aralıklardan oluşan akorlar

Hin.

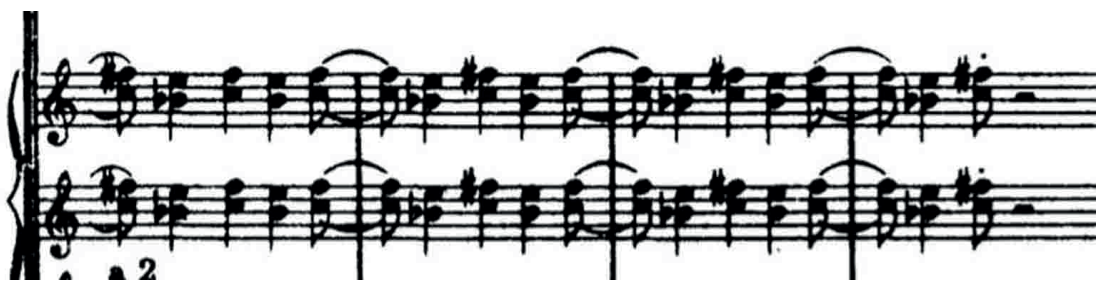

Şekil 15: Dördüncü bölümde kornoların duyurduğu artmış dörtlü aralıklar

\section{Altıncı Bölüm: Uranüs - Büyücü}

Uranüs'ün Antik Yunan mitolojisindeki karşılığg Prometheus karakteridir. Prometheus'un kişilik özellikleri arasında uzağı görme, önlemlerini zamanında alma, keskin zeka, kurnazlık bulunmaktadır. Bununla birlikte, uygar bir yaşam için mimarlık, gök bilimi, maden işleme, tıp, denizcilik gibi gerekli bilgi donanımına sahiptir. İyi yürekli bir karakterdir. İnsanlığın ilerlemesi için bilgilerini insanlığın hizmetine sunmuştur (Agizza, 2006, s. 156). Ancak mitolojik öyküsünde insanları kayırdığı için Zeus’u kızdırır ve onun tarafından cezalandırılır. Cezası insanların ateşten mahrum kalmasıdır. Prometheus ise duruma kayıtsız kalamaz ve güneşten taşıdığı ateşi insanların hizmetine verir.

Alan Leo'nun "Sentez Sanatı” kitabında ise Uranüs’ü "Uyandırıcı” başlığı altında incelemiştir. Uranüs'ün mitolojideki karşılığına benzer şekilde, bu kitapta da büyük bir enerji ve güç taşıyan bir karakteri vardır (Leo, 1912, s. 95). Leo’ya göre bu gezegenin taşıd1ğ1 özellikler arasında kendinden emin olma, sıra dişılık, değişkenlik, coşku, mizah, özgün fikirler, kural tanımazlık bulunmaktadır. Ani değişimleri, aydınlanma ve farkındalığı beraberinde getirir. 
Bu noktada bir saptama yapmak gerekiyor. Eserin ilk beş bölüm ve son bölüm adları ve müzikal esin kaynakları için mitolojiden yola çıkan ve astroloji ile desteklenen bir sembolizm söz konusudur. Ancak Holst'un altıncı bölüme verdiği isim bu iki alandan ayrı düşerek, bestecinin bir başka ilgi duyduğu alan olan Tarot ${ }^{\prime 34}$ dan alıntılanmıştır. Tarot uygulamasında da bir sembol dili kullanılır (Douglas, 1991, s. 13). Burada bir numaralı kartın adı "Büyücü”dür (Head, 1983, s. 20). Holst bu kartın dışa dönüklük, enerjik olmak, üretkenlik ve oyunbaz olmak ile ilişkilendirilen anlamını Uranüs'ün diğer mitolojik özellikleri ile birleştirmiştir (Head, 1983, s. 20).

Sıra dişılık, değişkenlik, kural tanımazlık, özgün olma: Bölümün ana teması dört notalık bir motiften oluşur. Bölümün başında $f f$ ses gürlüğünde bakır çalgılar tarafından duyurulur. $\mathrm{Bu}$ motifin aslına, farklı ses bölgelerine taşınmış ya da işlenmiş haline bölüm boyunca rastlarız. Besteci motif işleme yöntemlerinden taklit, eksiltme, arttırma, ses aralıklarını değiştirme yöntemlerini kullanarak motifi bölüm içinde sıklıkla duyurmuştur. Motifin biçim değiştirmesi Uranüs'ün değişkenliğini çağrıştırır. Besteci bu motifi iki zamanlı ve üç zamanlı olmak üzere iki farklı şekilde de işlemiştir. Zaman örgüsündeki bu düzensiz ilerleyiş, motifin tonaliteden kopuk, geleneksel olmayan yapısı da karakterin kural tanımazlığı ile örtüşür.

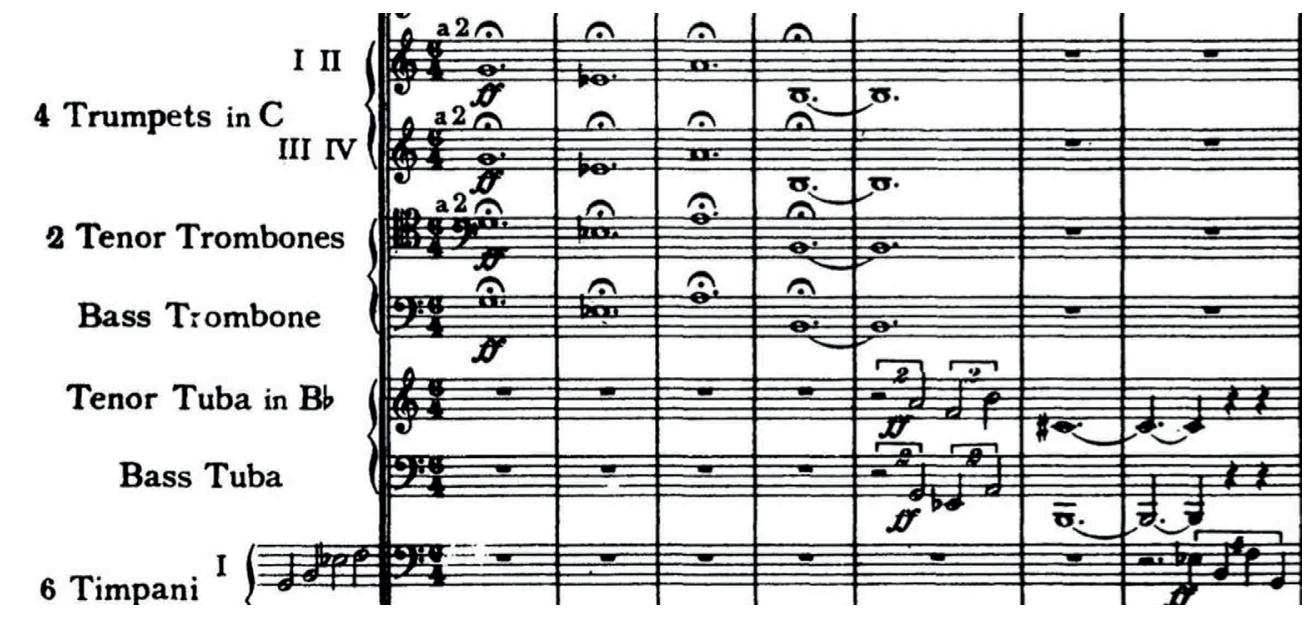

Şekil 16: Eserin “Uranüs - Büyücü” adlı altıncı bölümünün dört notalık bir motiften oluşan teması

Coşkulu, enerjik: Bölümün hızlı temposu Uranüs’ün enerjisini ve coşkusunu yansıtır. Bununla birlikte hızlı tempo bölümün son otuz ölçüsünde oldukça yavaş bir tempo ile

34 Tarot, Ortaçağ' da ortaya çıkmış oyun amaçlı tasarlanan 78 kartlık bir destedir. Bu kartlar zaman içinde bir bilinç okuma ve gelecek öngörüm yöntemi olarak kabul görmüştür ve günümüzde bu amacını korumaktadır (Douglas, 1991, s. 13). 
yer değiştirir. Bölümün başlangıcında duyduğumuz dört notalık motif, kendini tezat bir tempo ve ses gürlüğünde yeniden duyurur. Son bölüm olan Neptün'ün ruhani doğasına geçmeden önce bir durak olarak nitelenebilir.

Mizahi, neşeli: Bölümün içinde bestecinin yaylı çalgılarda duyurduğu pizzicatolar, çalg1lamada kullanılan ksilofon ve zil Uranüs'ün neşesini ve şakacı, mizahi yönünü anımsatır.

\section{Yedinci Bölüm: Neptün - Gizemli}

Neptün'ün Antik Yunan mitolojisindeki karşıllı̆ı Poseidon'dur. Bu karakterin Roma mitolojisindeki rolü, Antik Yunan mitolojisine göre daha azdır. Antik Yunan'da Poseidon denizin, göl sularının, sularla ilgili yeryüzü olaylarının ve "boğuk uğultuların" tanrısıdır. Gökyüzünün tanrısı Zeus’un ve “Ölüler Dünyası”nın tanrısı Hades’in kardeşidir. Geçinilmesi güç bir karakteri vardır (Agizza, 2006, s. 129).

Alan Leo'nun "Sentez Sanatı" kitabında bu gezegenden, mitolojik kökenine bağlı kalarak sislerin, belirsizliğin, düzensizliğin ve kaosun gezegeni olarak bahsedilmiştir. Belirli bir şeklin ya da yapının olmayışııı, soyutluğu simgeler. Kitapta gezegene ait başlık ise "Gizemli”dir (Leo, 1912, s. 103). Bununla birlikte sezgiler, boyut ötesi, öte alem, uyku hali, hipnoz, aldanma, aldatılma, gerçeklikten kopmak Neptün’ün taşıdığı diğer özelliklerdir (Leo, 1912, s. 106-110).

Tüm bu sembollerin ışığında eserin son bölümünü inceleyelim.

Sisler ardında olmak, belirsizlik, düzensizlik: Bölümün mi minör ve sol diyez minör tonik akorlarından alıntılanmış iki motiften oluşan tematik materyali belirsizliği, iki uç arasında gidip gelmeyi çağrıştırır. Bu bi-tonal ${ }^{35}$ tematik malzeme, tüm bölüm boyunca kendini gösterir. Bununla birlikte bölümün tamamında orkestranın $p p$ ses gürlüğünde çalması kullanılan armonik dil ve çalgılama ile gizemli bir hava oluşturur.

\section{Flutes}

Bass Flute

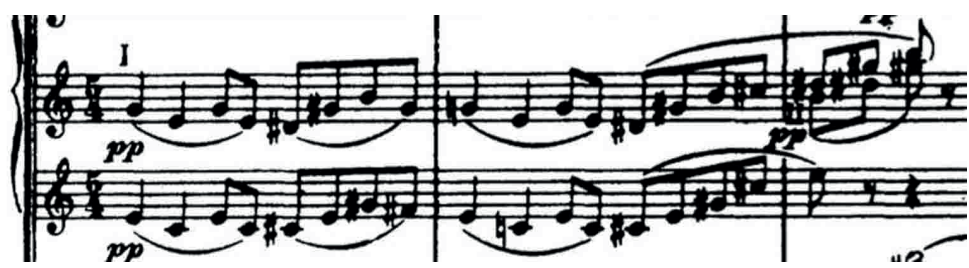

Şekil 17: Eserin 'Neptün - Gizemli' adlı yedinci bölümünün ilk üç ölçüsü ve bi-tonal tematik malzeme, 5/4'lük ölçü birimi ve $p p$ ses gürlüğü

35 İki tonluluk. 
Bölümün 5/4'lük aksak ölçü birimi ile yazılmış olması da Neptün'ün temsil ettiği düzensizlik ve kaos sembolizmi ile örtüşür.

Ruhani, gizemli, yaşamın ötesinde olan: Bu makalenin başında gezegenlerin sıralanışındaki sembolizmin gençliğin dinamizminden yaşlılığın bilgeliğine, dünyevi olandan ruhani ve ebedi olana doğru bir yolculuğu temsil ettiğini belirtmiştik. Neptün bu yolculukta son duraktır. Eserin bu bölümünde artık yaşamın sonunun belirsizliği hissedilir. Uranüs, Mars, Jüpiter gibi gücün ve dinamizmin tasvir edildiği bölümlerin aksine, bölüm boyunca tahta üflemeli çalgılar, arp ve yaylılar yoğunlukla duyulur. Eserin sonunda, artık bu yaşam enerjisi zayıflamıştır. Astronomik olarak Neptün, Güneş Sistemi'ndeki en uzaktaki, en soğuk, en son gezegendir. Sembolik olarak da güneşten uzakta olması ona yaşamın, ateşin canlılığından uzakta, yaşamın son sınırında bir anlam yükler. Ruhani, yaşamdan öte havayı eserde kullanılan kadınlar korosu oldukça başarılı bir şekilde oluşturur. Holst, bölümün sonunda duyulacak kadınlar korosunu sahne arkasında kapalı kapılar arkasında bir bölmeye, ayrı bir odaya yerleştirmiş, koronun partisi geldiğinde ise bu kapının sessizce açılıp koronun partisini seslendirmesini istemiştir. Dinleyici için uzaktan gelen, belirsiz bir ses olarak algılanmasını istemiştir. Kadınlar korosunun partisinde sözler bulunmaz. Bu gizemli koro Antik Yunan mitolojisindeki Sirenleri ${ }^{36}$ de çağrıştırır. Koronun besteci tarafindan kullanılma şekli, Neptün'e atfedilen denizler tanrısı, uyku ve ölüm sembolizmini çağrıştırır. Eser, koronun sesinin duyulmayacak olana giderek uzaklaşması ve yok olması ile son bulur. Besteci bunun için koro partisinin son ölçüsüne ${ }^{37}$ "ses uzakta kaybolana kadar bu ölçü tekrar edilecektir" ibaresini düşmüştür. Bu durum, var olandan başka bir aleme göçmek, ölüm temasını dinleyene hissettirir.

\footnotetext{
36 Antik Yunan mitolojisinde Sirenler Sirenum Scopuli isimli bir adada yaşayan deniz yaratıklarıdırlar. Efsaneye göre Sirenler söyledikleri şarkılarla denizcileri yaşadıkları kayalıklara doğru çeker ve onları uyutur ve bu şekilde ölümlerine sebep olurlar.
}

37 Aynı zamanda eserin de son ölçüsü 


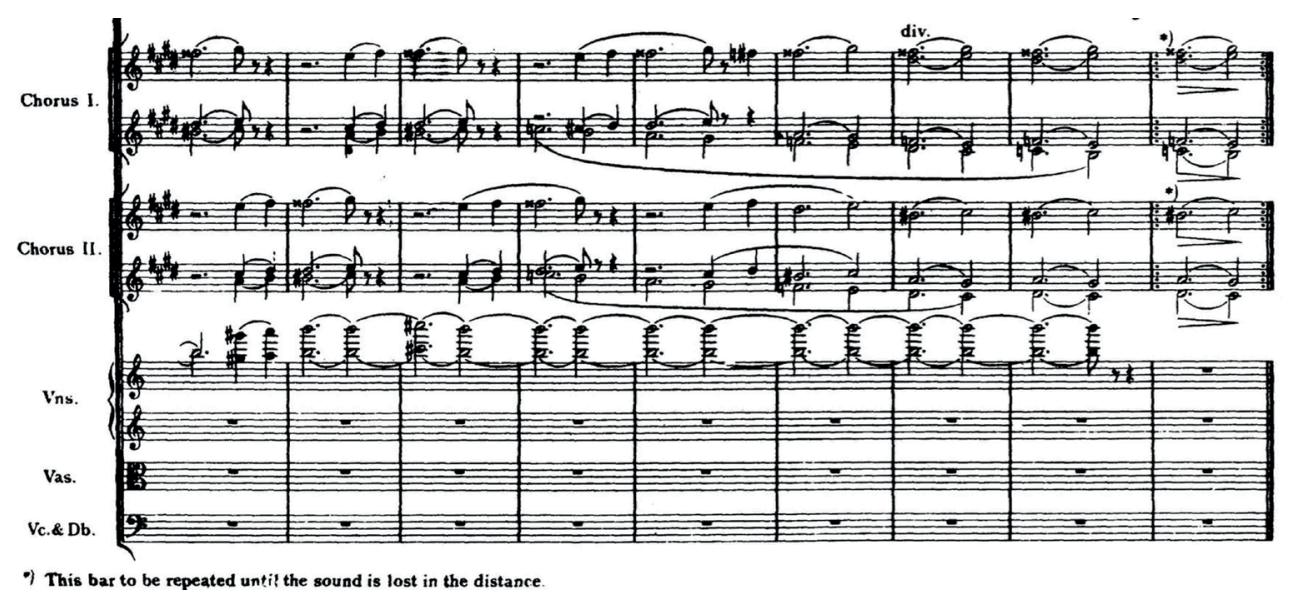

Şekil 18: Eserin "Neptün - Gizemli" adlı son bölümünün son dokuz ölçüsü, kadınlar korosu ve yaylı çalgılar partileri. Sol alt köşede bestecinin "ses uzakta kaybolana kadar bu ölçü tekrar edilecektir" ibaresi görülmektedir.

\section{Sonuç}

Bu makalede Gustav Holst’un Gezegenler Süiti adlı eserinin içindeki sembolizmin mevcut tüm kaynakları araştırılmış ve bu sembolizmin besteci tarafından esere nasıl yansıtıldığı detaylı olarak incelenmiştir. Makalenin sonucunda, Gustav Holst'un müzik dilinin çok zengin bir alandan beslenmiş olduğunu görmekteyiz. Eserde bestecinin salt büyük bir çoksesli gelenekten, geleneksel İngiliz halk müziğinden ve çağındaki müziğin yeniliklerinden etkilenmekle kalmadığı, bununla birlikte kendi iç dünyasından ve manevi ilgi alanlarından yepyeni bir müzikal dil oluşturduğu saptanmıştır.

Hayal gücünün, soyut kavramların, sembollerin müzikle bu derece örtüşebilmesi, müzik yoluyla betimlenebilmesi bestecilik açısından büyük bir ustalık göstergesidir. Bu eser, insanoğlunun zengin iç dünyasının ve inançlarının bir sanat eserinin oluşumunda ne derece etkin olduğunu da kanıtlar niteliktedir. Bu açıdan Gustav Holst müzik tarihinde içsel zenginliği ile kendi ilhamını oluşturan ve özgün müzikal dilini var eden ender bestecilerdendir. Var ettiği bu özgün stili ile kendinden sonra gelen kuşaklara 1şık tutmuştur.

Gezegenler Süiti'nin dinleyiciye sadece ustalıkla bestelenmiş bir eser olmadığını, aynı zamanda büyük bir düşünsel mirası da aktardığını görmekteyiz. Bu anlamda müziğin sadece dinleyiciye bir ses aktarımı olmadığını, çok boyutlu olarak değerlendirilmesi gerektiğini hatırlamak yerinde olacaktır. 


\section{Kaynakça}

Agizza, R. (2006). Antik Yunan'da mitoloji, masallar ve söylenceler. İstanbul: Arkeoloji ve Sanat Yayınları.

Arnason, H. H. (1998). History of Modern art: painting, sculpture, architecture, photography (Vol. 4). New York: Harry N. Abrams, Inc.

Britannica, T. E. (2008, Haziran 25). Horoscope. Retrieved Şubat 6, 2019, from Encyclopædia Britannica: https:// www.britannica.com/topic/horoscope

Britannica, T. E. (2018, 09 17). Gustav holst. (Encyclopædia Britannica, inc.) Retrieved 12 07, 2018, from Encyclopædia Britannica: https://www.britannica.com/biography/Gustav-Theodore-Holst.

Campbell, B. F. (1980). Ancient wisdom revived: a history of the theosophical movement. Berkeley: University of California Press.

Capell, R. (1928, Aralık 1). Gustav holst: notes for a biography (I). Musical times.

Cotterell, A. (1996). The encyclopedia of mythology. Londra: The Hermes House .

Douglas, A. (1991). The tarot-the origins, the meaning and uses of the cards. Londra: Sheridan Douglas Press.

Encyclopedia, N. W. (2016, Nisan 2016). Astrology. Retrieved Şubat 6, 2019, from New World Encyclopedia: http:// www.newworldencyclopedia.org/p/index.php?title=Astrology\&oldid=995443

Gombrich, E. H. (1958). The story of art. Londra: Phaidon.

Head, R. (1983). Holst - astrology and the modernism in "the planets". Tempo, New Series, 187, 15-22.

İlyasoğlu, E. (1999). Zaman içinde müzik (Vol. 5). İstanbul: Yapı Kredi Kültür Sanat Yayıncılık ve Ticaret Sanayi A.Ş.

Jones, B. (2013). Dictionary of world biography. Canbera, Australia: Anu Press.

Lambourn, D. (1987). Henry wood and schoenberg. Musical Times, 128 (1734), 422-427.

Leo, A. (1912). The art of synthesis. Londra: Modern Astrolgy Office, Imperial Buildings, Ludgate Circus E.C.

Luce, J. D. (2005). Roman myth. The Classical World, 98 (2), 202-205.

Mary Beard, J. N. (1998). Religions of Roma: A history. Londra: Cambridge University Press.

Melton, J. G. (2015, Şubat 25). Theosophy. Retrieved Şubat 7, 2019, from Encyclopædia Britannica: https://www. britannica.com/topic/theosophy

Merriam-Webster, https://www.merriam-webster.com/dictionary/meditation. (n.d.). Retrieved 2 15, 2019.

New World Encylopedia, C. (2017, 7 20). Gustav holst. (New World Encyclopedia) Retrieved 12 5, 2018, from New World Encyclopedia: http://www.newworldencyclopedia.org/p/index.php?title=Gustav_Holst\&oldid=1005649

Perowne, S. (1969). Roman mythology. Londra: Littlehampton Book Services Ltd.

Plütarkos. (2013). Plutarch complete works world's best collection. (W. W. Darryl Marks, Ed.) Londra: Everlasting Flames Publishing.

Rosivach, V. J. (1983). Mars, the lustral god. Latomus, 509-521.

Vaughan-Williams, R. (1920). Gustav holst I. Music \& Letters , 1 (3).

Wolfson, E. (2002). Roman mythology. New Jersey: Enslow Publishers. 